\title{
Tradeoff between Inflation and Unemployment in the Short Run: A Case of the Indian Economy
}

\author{
Dolly Singh \\ Department of Economics, Babasaheb Bhimarao Ambedkar University \\ Lucknow (Uttar Pradesh), India \\ E-mail: tanushrisingh1990@gmail.com \\ Nmp Verma \\ Department of Economics, Babasaheb Bhimarao Ambedkar University \\ Lucknow (Uttar Pradesh), India \\ E-mail: nmpverma@gmail.com
}

Received: March 24, 2016

Accepted: April 11, 2016

Published: April 27, 2016

doi:10.5296/ifb.v3i1.9378

URL: http://dx.doi.org/10.5296/ifb.v3i1.9378

\begin{abstract}
Unemployment and inflation are issues that are central to economic life of every developing country. This paper estimates the short-run tradeoff between inflation and unemployment for the Indian economy over the period 2009-2015, in order to know whether there is a tradeoff between inflation and unemployment. In short run there is inverse relationship of inflation with the unemployment, increase in inflation leads to decrease in unemployment and vice versa. This variable is subjected to Bi-variants regression analysis, with unemployment as its dependent variable in the first model, inflation in the second model and real GDP in the third model. The research outcomes proved the effective orientation of unemployment for the inflation and real GDP at statistically non-significance level. The findings proved the negative effect of unemployment for inflation and positive effect on real GDP. The unemployment is a continuously occurring phenomenon in all economies of developing countries where it is affecting highly the level of employment; price level, living standard of people, and real GDP. The findings proved the influential relationship between unemployment and inflation conditions, Unemployment and Real GDP conditions, but in our economic condition it is proved as non-significant. Consequently, the major policy
\end{abstract}


implication of these results is that concerted efforts should be made by policy makers towards restructuring the economy, managing price instability and level of employment.

Keywords: Unemployment, Inflation, Real GDP, Short run Philips curve, Bi-variate regression model 


\section{Introduction}

Inflation and unemployment economic problems both impact the common man life. High Productivity (Real GDP), price stability and low unemployment are the most desirable macroeconomic goals. In this regard in 1960, the concept of Phillips curve emerged, by A.W. Phillips who is the pioneer of the Phillips curve in UK. This curve suggests negative relationship between the rate of inflation and unemployment. There are two studies which provided explanations of the possible Phillips curve, relationship between the two variables in the short-run and the long run as; first one is, in short run, there is tradeoff between inflation and unemployment. Second, in the long run there is no significant tradeoff between inflation and unemployment. Therefore economists are in best interest to identify their relationship; there is a short run tradeoff between the rate of inflation and unemployment, (McConnell, 16th Ed). In this regard it has been also seen in many studies that there is short run tradeoff between Inflation and unemployment in different countries in different time periods.

The term inflation refers to increase in overall price level of goods and services in the economy which leads to decrease in the purchasing power of household. Because whenever prices increases, the value of money will depreciate and ultimately the real income of household will decrease.

The unemployment is that condition in the economy when supply of labor exceeds the demand of labor in the labor market. Similarly, a person who is willing to do the job but due to shortage of the jobs he or she could not find the job in the economy is known as unemployment.

The inverse relationship between inflation and unemployment rate as represented by Phillips curve is only a short-term relationship i.e., unstable, because it prevails for a limited period of time and there are factors which lead Phillips curve to another situation, and the major factor that leads to instability is unexpected inflation where the real wage for workers is declining, which motivates them to demand higher nominal wage, as a result the business reduces its demand for labor, which increases unemployment. So, unexpected inflation is accompanied by an increase in the unemployment rate. The macroeconomic goals which the government strives to achieve are the maintenance of stable domestic price level and full-employment. Macroeconomic performance is judged by three broad measures-unemployment rate, inflation rate, and the growth rate of output (Ugwuanyi, 2004). The long-run relationship between changes in the rates of GDP growth and unemployment is the rate of growth in potential output. Potential output is an unobservable measure of the capacity of the economy to produce goods and services when available resources, such as labor and capital, are fully utilized. The rate of growth of potential output is a function of the rate of growth in potential productivity and the labor supply when the economy is at full employment.

When unemployment rate is high, as it is now, then actual GDP falls short of potential GDP. This is referred to as the output gap. In the absence of productivity growth, as long as each new addition to the labor force is employed, growth in output will be equal to growth in the labor supply. If the rate of GDP growth falls below the rate of labor force growth, there will 
not be enough new jobs created to accommodate all new job seekers. Unemployment and inflation are issues that are central to both the social and economic life of every country. The existing literature refers to unemployment and inflation as constituting a vicious circle that explains the endemic nature of poverty in developing countries. And it has been argued that continuous improvement in productivity - which brings about the adequate supply of goods and services - is the surest way of breaking the vicious circle.

Problem of inflation in Indian economy is that, Inflation erodes the value of money that constrains people and firm to minimize their holding of cash. When price rises, sellers must use resources to change nominal prices. Then society's output of goods and services is reduced by devoting resources to these activities.

Problem of unemployment in India is that, Loss of output is the major problem of unemployment because the unemployed labor force does not add to the productivity. And they do not pay taxes, even tax-payers of the society also bear some of the output cost of the unemployed.

The main Objectives of this paper is focus on: Firstly: To determine the role of inflation, unemployment and Real GDP in Indian economy, secondly: To examine, is there any tradeoff exists between inflation and unemployment in Indian economy during study period and thirdly: To study the impact of Real GDP on unemployment in Indian Economy.

\section{Theoretical Framework and Literature Review}

\subsection{Theoretical Framework}

Phillips Curve was named after the British economist A.W. Phillips, who first examined the relationship between the rate of unemployment and the rate of money wage changes. His analysis was based on data for the United Kingdom from 1861-1957. Phillips derived an empirical result that there was an inverse relationship between the rate of unemployment and the rate of increase in money wages. Phillips found a consistent inverse relationship: when unemployment was high, wages increased slowly; when unemployment was low, wages rose rapidly. The Phillips curve represents the average relationship between unemployment and wage behavior over the business cycle. It illustrates the rate of wage inflation that would result if a particular level of unemployment persisted for some time. After Phillips' work, economists studied the Phillips curve; some validated it while others refuted it. Thus, Friedman (1977) contended that there is no trade-off between inflation and unemployment in the long run, representing a monetarist view of Phillips curve. He argued that, any attempt to hold the unemployment rate at an artificially low level would cause inflation to accelerate indefinitely. He argued that, there is a natural rate of unemployment where the real wage rate is in long run equilibrium for employment rate to be below the natural rate, employers and potential employees must be willing to be hired.

\subsection{Literature Review}

Karanassou \& Sala (2010) argued there is a tradeoff between inflation and unemployment in long run because of money and productivity growth which leads to decrease in 
unemployment, while supply shock like oil prices which leads to increase in unemployment. In the case of 1970, monetary expansion led to increase in inflation and reduced the unemployment which was very negligible, and slowdown in productivity also led to increase in inflation and unemployment. He argued that increase in productivity growth causes decrease in inflation and also fall in unemployment. Hussein Ali Al-Zeaud (2011) argued that there is no tradeoff between inflation and unemployment in Jordan economy between 1984 and 2011 because foreign labor were not involved in the unemployment rate calculation. He used Granger-Causality test to check relationship between variables and the direction of causation and techniques depends on testing stationary, integration, co-integration as per-requisites. Liu \& Jansen (2010) had argued that, the basic concept of traditional Phillips curve model holds that there is a tradeoff between inflation and real activity (unemployment), therefore, it is still used to forecast inflation. Berger (2010), they find that increase in cyclical unemployment will lead to decrease in output which ultimately causes to decrease in inflation. Afzal \& Awais (2012) argued that there is a tradeoff between inflation and unemployment in short run by using latest version of empirical study of Phillips curve for Pakistan. He found that reduced form of Phillips curve structure reveals that the expected inflation is significant for all periods. He said that high economic growth, price stability and low unemployment are the most enviable macroeconomic goals. Inflation is regarded as a problem when the inflation rate is too high and rising. Unemployment results from lack of employment opportunities and is a permanent feature of the economy. Das \& Martin (2013) used Phillips curve to estimate the output gaps for Indian Data. And modified Hodrick-Prescott filter with a non constant smoothing parameter. He allows the smoothing parameter over time and its value reflects the nature and magnitude of supply and demand shock in India. Quin \& Wang (2013) he argued that there is a visual relationship between the inflation and unemployment. He used statistical and consistent data for economic condition of china. He also used correlation of co-efficient and causality between inflation rate and unemployment rate for the period of 1978 to 2011 . He proved empirical Phillips curve is ineffective to find casual relationship between the inflation rate and unemployment rate in China. Franz (2010) concluded that it is very hard to assess the NAIRU, if the joint relationship of inflation, wage increases and unemployment get worse because NAIRU is the point where inflation is constant at consistent rate of unemployment. Apel \& Jansson (1999) argued that Phillips curve equation also helps in precision of estimating the potential output and the NAIRU. Sagar Katria et al. (2011) Sukkur Institute of Business Administration, and Sukkur aimed to identify the relationship between inflation and unemployment in SAARC countries from the perspective of Phillips curve. Unbalanced annual panel data of 8 SAARC members (Afghanistan, Bangladesh, Bhutan, India, Maldives, Nepal, Pakistan and Sri Lanka) and 6 expected member of SAARC (Republic of China, Russia, Indonesia, Iran, Myanmar and South Africa) had been used for the period 1980-2010. This paper found significant results; there is a negative relationship between inflation and unemployment rate in the SAARC Countries. Concept of Phillips curve holds true. Still on the relationship between unemployment and inflation, Studies by Aminu \& Anono (2012) using the Augmented Dickey-Fuller technique, revealed that there is no causation between unemployment and inflation and that a long-term relationship exist between the two. Also, the study revealed a negative relationship between unemployment and 
inflation and a minimal applicability of various theories of unemployment and inflation in India

\section{Methodology and Data Source}

The secondary data are used for this study period from 2009-2015. Therefore, data were sourced from Central Bank of India (CBI) Statistical bulletin which includes; data on real gross domestic production (RGDP), consumer price index proxy for inflation (INF) and Ministry of labor \& employment for unemployment rate (UNEMP). The ordinary least square method and Bi-variate regression model of econometric approach was used in estimation.

\subsection{Model Specification}

To study empirically on the relationship between unemployment and inflation in Indian economy, a model will be employed. In the first model, inflation, Real GDP will be regressed on unemployment; in order to ascertain the impact of the explanatory variables on the explained variable. In the second model, unemployment, Real GDP will be regressed on Inflation and in the third model, inflation and unemployment will be regressed on Real GDP. The model of the form will be formulated which is adopted by Bello Malam Sa'idu1 (2015) as stated below.

From the foregoing analysis, three models can be written in its functional form as follows:

\section{UNEMP $=$ f (INF, RGDP)}

INF $=\mathbf{f}($ UNEMP, RGDP)

\section{RGDP $=\mathbf{f}($ UNEMP, INF $)$}

Where, UNEMP $=$ unemployment Rate, INF $=$ Inflation Rate, Real GDP $=$ Real Gross Domestic Product and $\mathrm{f}=$ functional relationship

Expanding the model into a linear mathematical relationship, we have,

$$
\begin{aligned}
& \text { UNEMP }=\beta_{0}+\beta_{1} \text { RGDP }+\beta_{2} \text { INF } \ldots \ldots \ldots \ldots \ldots \ldots \ldots \ldots \ldots \ldots \ldots . . . \ldots \ldots \ldots \ldots \\
& \text { INF }=\beta_{0}+\beta_{1} \text { UNEMP }+\beta_{2} \text { RGDP ........................eq } 2
\end{aligned}
$$

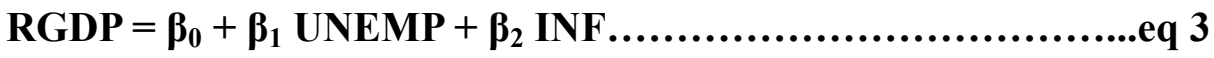

Econometrics model, by including stochastic term (et), thus our model becomes;

$$
\begin{aligned}
& \text { UNEMP }=\beta_{1}+\beta_{1} \text { RGDP }+\beta_{2} \text { INF }+ \text { et } \ldots \ldots \ldots \ldots \ldots \ldots \ldots \ldots \ldots \ldots \text {. eq } 4 \\
& \text { INF }=\beta_{0}+\beta_{1} \text { UNEMP }+\beta_{2} \text { RGDP }+ \text { et } \ldots \ldots \ldots \ldots \ldots \ldots \ldots \ldots \ldots \ldots . . . . \ldots \ldots
\end{aligned}
$$

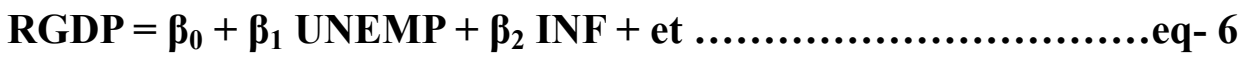

Where, $\boldsymbol{\beta}_{\mathbf{0}}$ is intercept depicting unemployment when the explanatory variables are equal to zero in first model, inflation in the second model when the explanatory variables are equal to zero and Real GDP in the third model when the explanatory variables are equal to zero. $\boldsymbol{\beta}_{\mathbf{0}}$ and $\boldsymbol{\beta}_{1}$ are the co-efficient or parameters attached to the explanatory variables. The inclusion 
of the stochastic or error term (et) in the above model is to capture the impact of other variables that are not included in the models.

\subsubsection{Inflation Rate}

Table 1. Inflation rate of India in percentage during 2009-2015

\begin{tabular}{|c|c|}
\hline Years & Inflation Rate (\%) \\
\hline $2009-2010$ & 10.83 \\
\hline $2010-2011$ & 12.11 \\
\hline $2011-2012$ & 8.94 \\
\hline $2012-2013$ & 7.35 \\
\hline $2013-2014$ & 5.98 \\
\hline $2014-2015$ & 6.37 \\
\hline
\end{tabular}

Source: RBI \& Worldwide Inflation

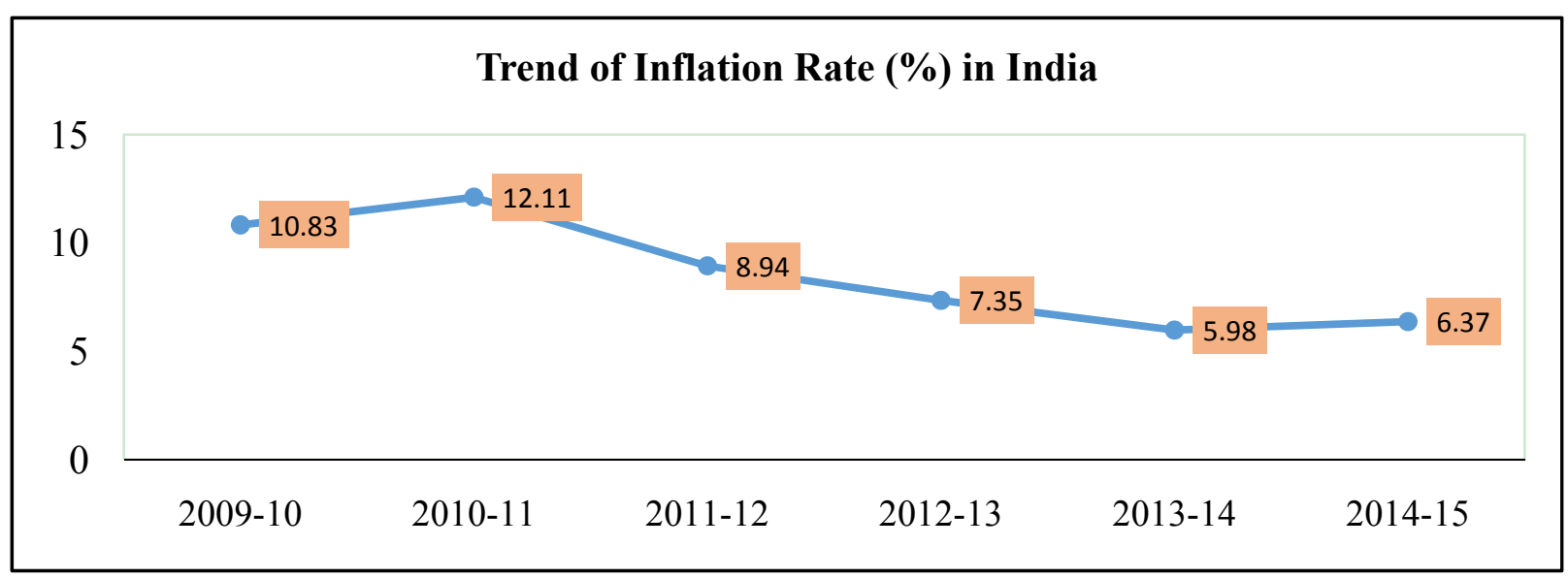

Figure 1. Inflation rate (\%) in India

The figure 1 shows average inflation rate (\%) in India from the year 2009-2015. In year $2010-2011$ inflation rate is increased by $1.28 \%$, but decreased by $3.17 \%$ in $2011-2012$. It was decreased continuously and reached to $6.37 \%$ in 2014-2015. From the above data we can conclude that situation of inflation in India sometime increased or decreased i.e., fluctuated not linearly changed. 
3.1.2 Unemployment Rate (\%) in India during (2009-2015)

Table 2. Average unemployment rate of India in percentage during 2009-2015

\begin{tabular}{|c|c|}
\hline Years & Unemployment Rate (\%) \\
\hline $2009-2010$ & 10.1 \\
\hline $2010-2011$ & 10.8 \\
\hline $2011-2012$ & 9.8 \\
\hline $2012-2013$ & 8.5 \\
\hline $2013-2014$ & 8.8 \\
\hline $2014-2015$ & 7.3 \\
\hline
\end{tabular}

Source: Ministry of labor \& employment, government of India

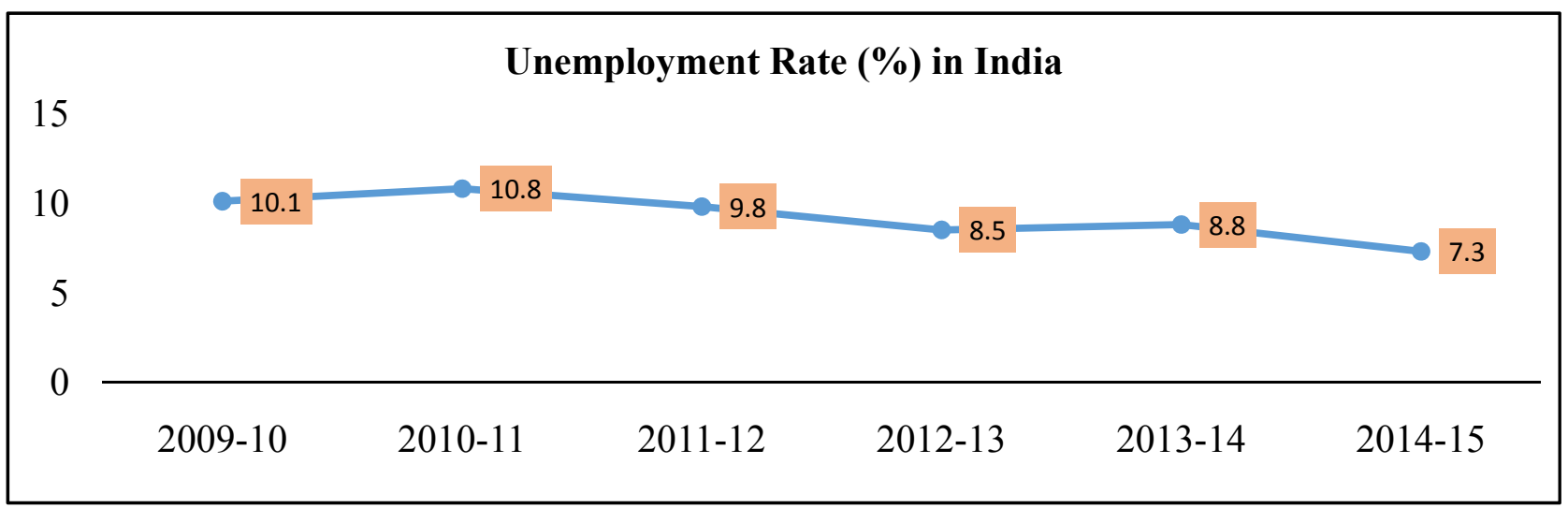

Figure 2. Trends of unemployment rate (\%) in India

From the figure 2, it has seen that unemployment rate is increased only by $0.7 \%$ in 2010-2011 but decreased by 1\% in year 2011-2012. It decreased continuously reached to 7.3 in year 2014-2015. Unemployment rate sometime increased and decreased as shown in the above graph, so it seen that, there is fluctuation in unemployment rate in Indian economy. Unemployment Rate in India decreased by 4.90 percent in 2013 from 5.20 percent in 2012. Unemployment Rate in India averaged 7.32 percent from 1983 until 2013, reached an all-time high of 9.40 percent in 2009 and recorded lowest of 4.90 percent in 2013.

3.1.3 Short-Run Tradeoff between Inflation-Unemployment in India During (2009-2015)

Table 3. Percentage wise inflation and unemployment rate in India

\begin{tabular}{|c|c|c|}
\hline Years & Inflation Rate (\%) & Unemployment Rate (\%) \\
\hline $2009-10$ & 10.83 & 10.1 \\
\hline $2010-11$ & 12.11 & 10.8 \\
\hline $2011-12$ & 8.94 & 9.8 \\
\hline $2012-13$ & 7.35 & 8.5 \\
\hline $2013-14$ & 5.98 & 8.8 \\
\hline $2014-15$ & 6.37 & 7.3 \\
\hline
\end{tabular}

Source: Ministry of labor \& employment, government of India 


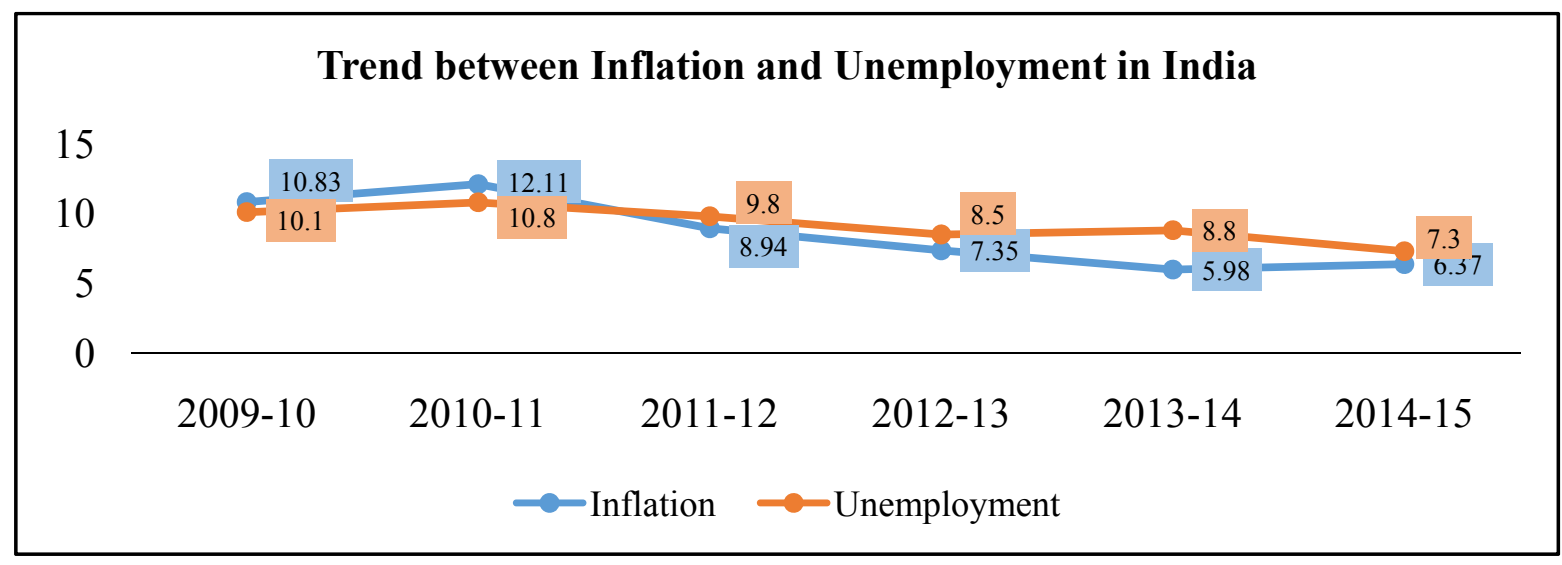

Figure 3. Trend of inflation and unemployment rate in India

From the figure 3, it has seen that whether Phillips curve situation exist in our Indian economy during study period .Phillips curve means inverse relationship between inflation and unemployment in the short run period. The following table showing the fluctuation situation of inflation - unemployment over preceding year.

Table 4. Relationship between inflation-unemployment in India

\begin{tabular}{|c|c|c|}
\hline Variation over preceding year & Inflation rate (\%) & Unemployment rate (\%) \\
\hline $2010-11$ over $2009-10$ & 1.28 & 0.7 \\
\hline $2011-12$ over $2010-11$ & -3.17 & -1 \\
\hline $2012-13$ over $2011-12$ & -1.59 & -1.3 \\
\hline $2013-14$ over $2012-13$ & -1.37 & 0.3 \\
\hline $2014-15$ over $2013-14$ & 0.39 & -1.5 \\
\hline
\end{tabular}

Source: Compiled by Author.

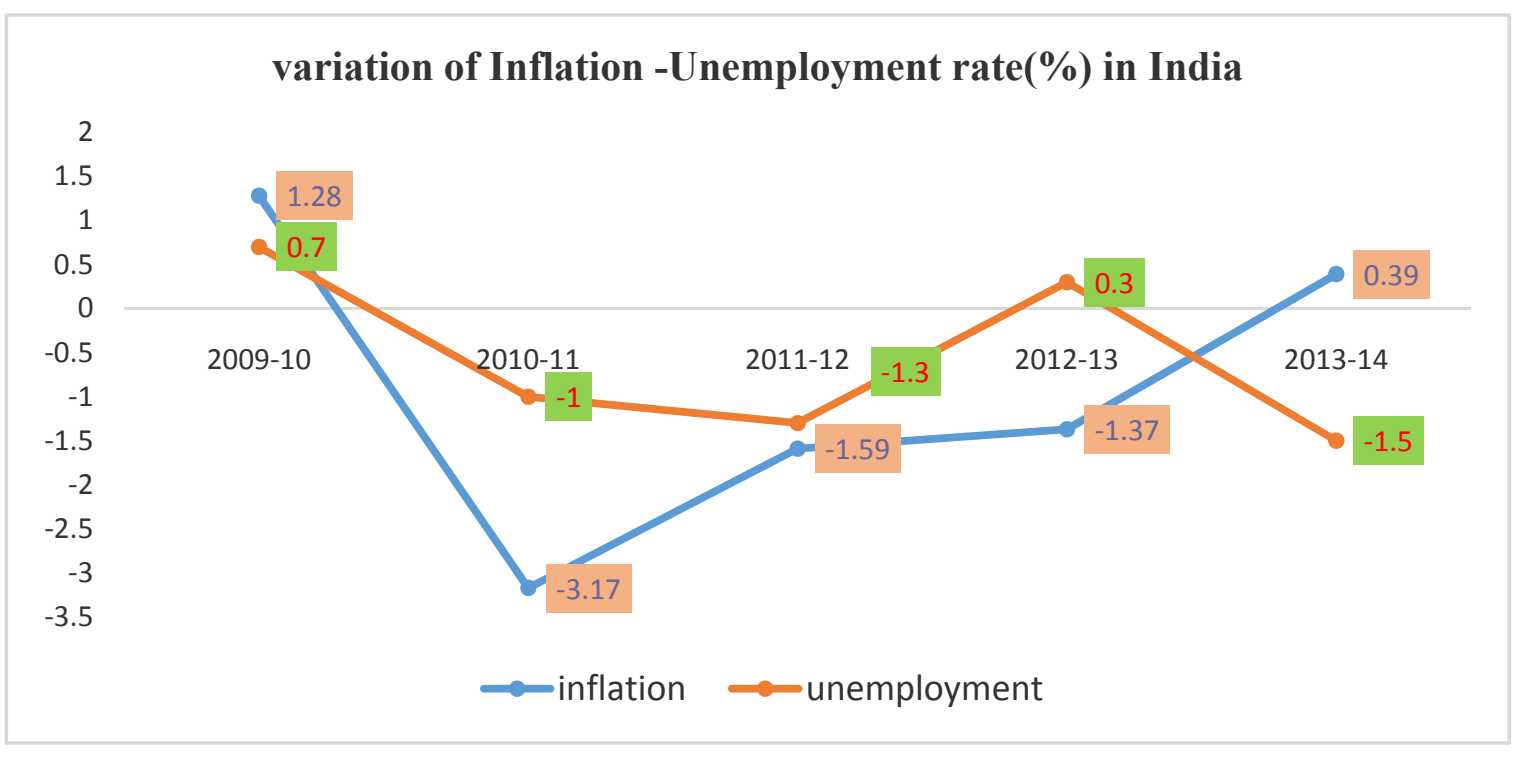

Figure 5. Relationship between unemployment and inflation in India according to Phillips curve concept 
Above figure 5 shows the variation of Inflation and unemployment rate in India during study period 2009-2015. Variation in the year 2010-2011 shows that percentage of both parameters is increased, whereas in year 2011-2012 inflation rate was decreased and unemployment rate also decreased as we see in the figure. Similarly, in the year 2012-2013 both are decreased but in 2013-2014 it has seen that inflation decreased while unemployment increased in a minor way. Finally in 2014-2015 inflation increased sparsely and unemployment decreased. From above data it observed that in India Phillips curve concept does not exist. Thus, it can be concluded that there was no relationship between inflation and unemployment in India during study period. The short run tradeoff does not exist between inflation and unemployment in Indian Economy. The earlier studies (Nwaobi, 2009; Kotia, 2013; Das \& Martin, 2013; Sa'idu \& Muhammad, 2015) also concluded that tradeoff does not exist in developing countries like India.

3.1.4 Real GDP (\%) in India During (2009-2015)

Table 5. Average real GDP data in percentage of India

\begin{tabular}{|c|c|}
\hline Years & Real GDP (\%) \\
\hline $2009-2010$ & 7.4 \\
\hline $2010-2011$ & 9.4 \\
\hline $2011-2012$ & 7.2 \\
\hline $2012-2013$ & 6.5 \\
\hline $2013-2014$ & 3.2 \\
\hline $2014-2015$ & 6.3 \\
\hline
\end{tabular}

Source: Monetary policy report (2015), Reserve Bank of India.

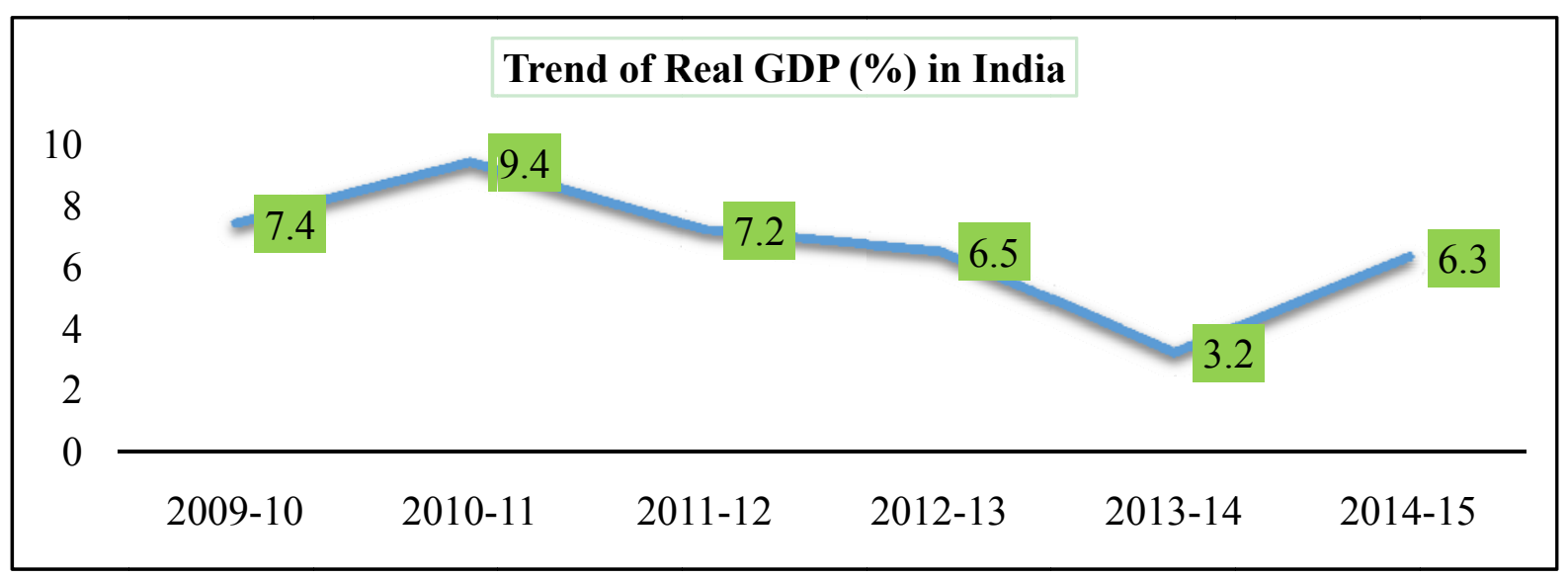

Figure 6. Trends of real GDP (\%) in India in different year

The above figure 6 shows the trend of Real GDP of India during study period (2009-2015). During 2010-2011 it increased by $2.8 \%$ and decreased by $2.2 \%$ in 2013-2014. Further, it has been decreased by $0.7 \%$ in 2012-2013, again it decreased by $3.3 \%$ in 2013-2014 and finally it has increased by 3.1\% in year 2014-2015 i.e., 6.3\% Real GDP growth in India. Real GDP growth should be higher in our Indian economy to make balance economically. Lower Real GDP is shows in developing countries like Indian economy. 
3.1.5 Relationship between Unemployment and Real GDP

Table 6. Average percentage of unemployment and real GDP in India during (2009-2015)

\begin{tabular}{|c|c|c|}
\hline Year & Unemployment Rate (\%) & Real GDP (\%) \\
\hline $2009-2010$ & 10.1 & 7.4 \\
\hline $2010-2011$ & 10.8 & 9.4 \\
\hline $2011-2012$ & 9.8 & 7.2 \\
\hline $2012-2013$ & 8.5 & 6.5 \\
\hline $2013-2014$ & 8.8 & 3.2 \\
\hline $2014-2015$ & 7.3 & 6.3 \\
\hline
\end{tabular}

Source: Ministry of labor \& employment, government of India.

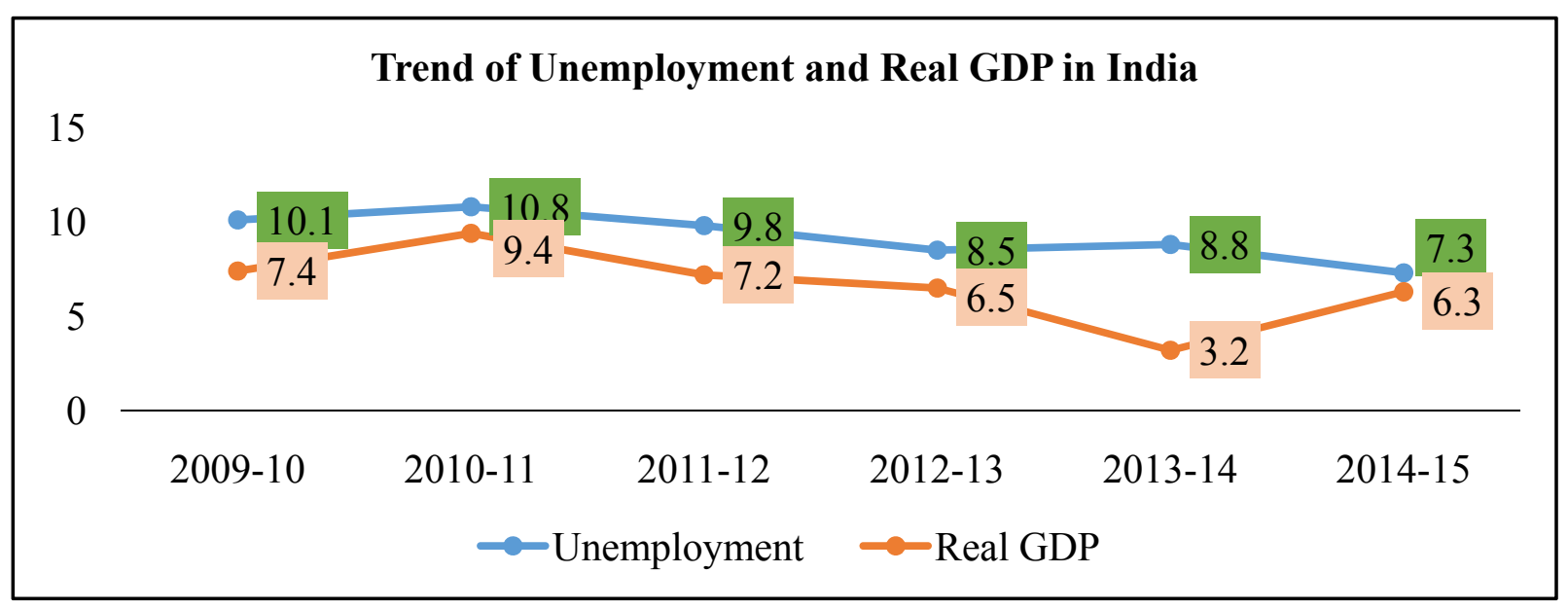

Figure 7. Trends of real GDP vs. unemployment rate in India

The above figure 7 shows the relationship between Unemployment and Real GDP in India during study period. In short run there was no impact of Real GDP on Unemployment in developing countries like India. But it has seen from the Okun'S law theorem, if there is 3\% change in Real GDP then it should be $1 \%$ fall in unemployment. To see whether this situation happens in Indian economy during study period. The following is the table of variation in different year:

Table 7. Relationship between real GDP and unemployment according to Okun's law

\begin{tabular}{|c|c|c|}
\hline Variation over preceding year & Real GDP Growth rate (\%) & Unemployment rate (\%) \\
\hline $2010-11$ over 2009-10 & +2 & +0.3 \\
\hline $2011-12$ over 2010-11 & -2 & -1.0 \\
\hline $2012-13$ over 2011-12 & -1 & -1 \\
\hline $2013-14$ over 2012-13 & -3.2 & -0.3 \\
\hline 2014-15 over 2013-14 & +3.1 & -1.5 \\
\hline
\end{tabular}

Source: Compiled by author 


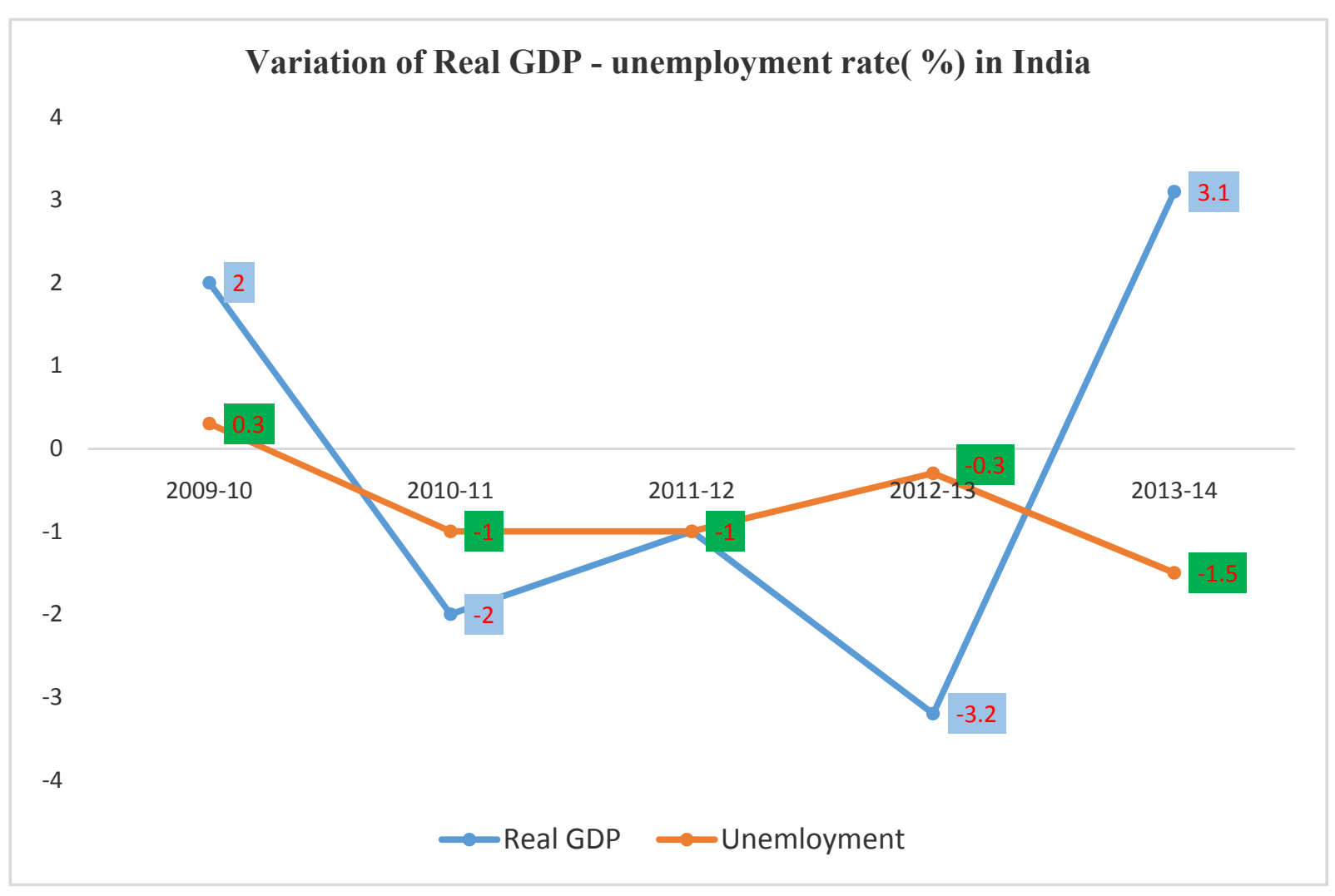

Figure 8. Variation between real GDP-unemployment in India

From the estimates shown in Table 7 in the year 2011-2012 over 2010-2011 till the year 2013-2013 over 2012-2013 the Okun's law theorem is not applicable while, it clearly shows in the above table that Okun's law theorem is applicable in 2014-2015 over 2013-2014. Because it has been seen from the changes in RGDP growth rate and unemployment rate in above table which can only be proved according to the Okun's law, it can be reported that there is no relationship between Real GDP and unemployment during 2009-2010 to 2012-2013. However, it is not true in case of year 2013-2014 to 2014-2015, because Okun's theory is applicable and Real GDP have an impact on unemployment.

\section{Data Analysis and Discussion of Result}

The analysis begins with the descriptive statistics which will enable us to explore the time series properties of the variables. The descriptive statistics employed in the study are the summary of statistics.

Table 8. Descriptive statistics of unemployment, inflation rate and real GDP

\begin{tabular}{|l|c|c|c|c|}
\hline Variables & Minimum & Maximum & Mean & Std. Deviation \\
\hline Unemployment Rate & 7.3 & 10.8 & 9.32 & 1.73 \\
\hline Inflation Rate & 4.74 & 10.26 & 7.07 & 2.1 \\
\hline Real GDP & 11.54 & 18.66 & 14.12 & 2.9 \\
\hline
\end{tabular}


The above Table 8 explains the descriptive statistics about unemployment, inflation, and GDP. It can be seen that minimum and maximum values of Unemployment have little gap in the six years period. The gap indicates that India's unemployment is consistent and less volatile. The minimum and maximum values of inflation have a big gap in the six years period. The gap indicates that India's inflation is inconsistent and highly volatile. While the variation and gap between maximum and minimum values can be found comparatively low, but still inconsistent in some years. The value of the GDP can be found low while in some cases it is found higher. Therefore it is also found vibrant.

\subsection{Interpretation of the Three Bi-Variate Regression Model}

The two equations were taken for the regression to shown the result of unemployment impact on inflation-Real GDP and other to show the Real GDP impact on unemployment-inflation. The equations are,

$$
\begin{aligned}
& \text { UNEMP }=\beta_{0}+\beta_{1} \text { RGDP }+\beta_{2} \text { INF }+ \text { et............eq } 4 \\
& \text { INF }=\beta_{0}+\beta_{1} \text { UNEMP }+\beta_{2} \text { RGDP }+ \text { et..............eq } 5 \\
& \text { RGDP }=\beta_{0}+\beta_{1} \text { UNEMP }+\beta_{2} \text { INF }+ \text { et.............eq (6) }
\end{aligned}
$$

The values of unemployment has been shown -17.091477 i.e., a negative impact on the RGDP and INF in Indian economy. The value of Inflation shows -3112.57375 i.e., negative impact on the UNEMP and RGDP in Indian economy. The value of Real GDP shows 208.9422 i.e., also negative impact on the UNEMP and INF in Indian economy but no significant values. The correlation between Inflation and unemployment is negative, thus insignificant. There is no relationship between inflation and unemployment in developing country like India. The correlation between real GDP growth and unemployment is very important for policy makers in order to obtain a sustainable rise in living standards. If GDP growth rate is below its natural rate it is indicated to promote employment because this rise in total income will not generate inflationary pressures. In contrast, if the GDP growth is above its natural level, policy makers will decide not to intensively promote the creation of new jobs in order to obtain a sustainable growth rate which will not generate inflation.

To check whether hypothesis of this work is rejected or accepted. The hypothesis is, Null hypothesis (H0): There is insignificant relationship between inflation and unemployment. Yes, this (H0) true there is insignificant relationship shown between inflation and unemployment, there is negative relation shown between this two variable from the values -17091477. Null hypothesis (H0): Real Gross domestic product (GDP) has no significant impact on unemployment in India. This (H0), rejected i.e., true RGDP has insignificant impact on unemployment in Indian Economy. 
Table 9. Regression analysis between inflation, unemployment and real GDP

\begin{tabular}{|l|l|l|l|}
\hline \multicolumn{4}{|l|}{ Regression (model 1) fit between UNEMP $=$ INF, Real GDP (2009-2015) } \\
\hline $\mathbf{R}^{2}$ (r- Square) & $\begin{array}{l}\text { Adjusted } \\
\text { R-squares }\end{array}$ & f-test & Significant level \\
\hline 0.763772 & 0.606287 & 4.0635 & 0.1975 \\
\hline Regression (model 2) fit between INF $=$ UNEMP,RGDP (2009-2015) & f- test \\
\hline $\mathbf{R}^{2}$ (r-Square) & $\begin{array}{l}\text { Adjusted } \\
\text { R-Squares }\end{array}$ & Significant level \\
\hline 0.962436 & 0.937394 & 38.43223 & 0.00728 \\
\hline Regression (model 3) fit between Real GDP= UNEMP,INF (2009-2015) & Significant level \\
\hline $\mathbf{R}^{2}$ (r-square) & $\begin{array}{l}\text { Adjusted } \\
\text { R-squares }\end{array}$ & f-test & 0.010561 \\
\hline 0.951864 & 0.919773 & 29.66177 & \\
\hline
\end{tabular}

The above Table 9 explains correlation between unemployment rate and Inflation rate. The findings are showing that only 0.7 percent variability has been recorded in the dependent variable GDP due to inflation. The value of F-test is found as below the standard value of rule of thumb 4.06 and significance level is just 0.1975. All these findings are disclosing that model is not satisfactory. On other part of the Table 9 explains the model fitness between inflation and unemployment rate. Here it is found that 0.96 percent variability in unemployment rate is due the inflation during the 2009-2015. The research findings provides information about F-test 38.43 and which is above the standard 4.00 i.e., the level of significance is just above the higher level of the significance, therefore, it can be concluded that the model is satisfactory between inflation rate and unemployment rate and Real GDP. The last part explains the model fitness between Real GDP and Unemployment rate. Here it is found that 0.95 percent variability in unemployment rate is due to the inflation during the 2009-2015. The research findings provides information about f-test 29.66 and which is above the standard 4.00 i.e., the level of significance is just above the higher level of the insignificance.

Table 10. Bi -Variate regression result of three equation

\begin{tabular}{|c|c|c|c|c|c|}
\hline \multicolumn{6}{|c|}{ Regression result between Unemployment = Inflation, Real GDP } \\
\hline Variables & Co-efficient & Std. Error & t-test & t-prob. & $\begin{array}{l}\text { Significant } \\
\text { level }\end{array}$ \\
\hline Constant & 3.323638 & 1.959568 & 1.696107 & 0.188435 & 0.1975 \\
\hline RGDP & 0.516477 & 0.237332 & 2.176178 & 0.117771 & \\
\hline INF & -0.18398 & 0.327438 & -0.56187 & 0.613446 & \\
\hline \multicolumn{6}{|c|}{ Regression result between Inflation $=$ Unemployment, RGDP } \\
\hline Variables & Co-efficient & Std. Error & t-test & t- prob. & $\begin{array}{l}\text { Significant } \\
\text { level }\end{array}$ \\
\hline Constant & -6.26727 & 2.070694 & -302665 & 0.056461 & 0.00728 \\
\hline UNEMP & 1.162728 & 0.272325 & 4.269637 & 0.023581 & \\
\hline RGDP & 0.62212 & 0.170106 & 3.657237 & 0.035313 & \\
\hline \multicolumn{6}{|c|}{ Regression result Real GDP $=$ Unemployment, INF } \\
\hline Variables & Co-efficient & Std. error & t-test & t-prob. & $\begin{array}{l}\text { Significant } \\
\text { level }\end{array}$ \\
\hline Constant & 8.557254 & 2.726748 & 3.138264 & 0.051733 & 0.010561 \\
\hline UNEMP & -1.72805 & 0.49934 & -3.46066 & 0.040621 & \\
\hline INF & 1.672243 & 0.275061 & 6.079532 & \begin{tabular}{|l|}
0.008935 \\
\end{tabular} & \\
\hline
\end{tabular}


The above Table 10 shows the statistical results of regression tests. The regression results between the two variables Unemployment and inflation shows a negative unit change from inflation. The findings are proving the phenomenon in such way that one unit change in inflation brings negative 0.018 unit change in unemployment. But the value of t-test is found below the tabulated or standard value of the rule of thumb. Finally for the significance level, it can also be observed to be highly above the required level that is 0.19 , therefore, the findings are providing statistical grounds for the rejection of proposed hypothesis $\mathrm{H} 1$ : unemployment non-significantly influences Inflation rate of the Indian economy. On the Second Model, the regression between inflation and unemployment is found to show a positive unit change from Unemployment, the findings are proving the phenomenon in such way that one unit change in inflation brings positive 1.162 unit change in unemployment. But the value of t-test is still below the tabulated or standard value of the rule of thumb. Finally for the significance level is also highly above the required level that is 0.007 , therefore, the findings are providing statistical grounds for the rejection of proposed hypothesis $\mathrm{H} 2$ : Inflation insignificantly influences unemployment rate of the Indian economy .In the third model, the Regression between Real GDP and Unemployment is found to be negative unit change from the unemployment and positive from the Inflation. The findings are proving the phenomenon in such way that one unit change in Unemployment brings negative 1.72 unit change in unemployment. But the value of t-test is still below the tabulated or standard value of the rule of thumb. Finally the significance level is also high above the required level that is 0.01 , therefore, the findings are providing statistical grounds for the rejection of proposed hypothesis H3: Real GDP has no significantly impact on Indian Economy.

For the first model, The R-square of 0.76 illustrates that $76 \%$ variation in unemployment is explained by Real GDP and Inflation in first model. The R-square of 0.76 illustrates that $76 \%$ variation in Unemployment is explained by Inflation and Real GDP in the first model. Also, the adjusted R-square with a value of 0.60 which shows $60 \%$ variation in dependent variable is explained by independent variable when the degree of freedom is taken care off. The F-statistics values for unemployment and Inflation is greater than 2 which indicate the rejection of the hypothesis that there is causation between inflation and unemployment. This confirms that unemployment substantially affect inflation while Real GDP has little substantial effect.

For Second model, the R-square of 0.96 illustrates that $96 \%$ variation in Inflation rate is explained by Unemployment and Real GDP in the third model. Also, the adjusted R-square with a value of 0.93 which shows $93 \%$ variation in dependent variable is explained by the independent variable when degree of freedom is taken care off. The F-Statistics values for Inflation and unemployment is 2 which rejects the hypothesis that there is no relationship between inflation- unemployment. This confirms that Inflation substantially affect unemployment while Real GDP has little substantial effect.

For Third model, The R-square of 0.95 illustrates that 95\% variation in Real GDP growth is explained by unemployment and Inflation in the second model. Also, the adjusted R-square with a value of 0.91 which shows $91 \%$ variation in dependent variable is explained by the independent variable when the degree of freedom is taken care off. The F-statistics values for 
Real GDP and unemployment is greater than 2 which indicate the rejection of the hypothesis that there is causation between unemployment and Real GDP growth. This confirms that Real GDP substantially affect unemployment while Inflation has little substantial effect.

\subsection{Discussion}

Experiential results as evidence proved the relationship between inflation, GDP and unemployment as influencing each other at insignificant level. The results of the quantitative outcome proved that Unemployment is one of vibrant and influential phenomenon in the economy of India. And the inflation needs to be considered as one of the important factor for the economies to consider it towards strategic economic decisions. The quantitative factors of the economies are mainly to be considered for the strategic decision to lead the rational approaches in the economic decisions for Indian economy.

\section{Interpretation of Results}

The intercept of Real GDP when all explanatory variables are held constant is $\mathbf{8 . 5 5 7 2 5 4}$.

The coefficient of unemployment, tells us that when there is a unit increase in the unemployment, Real GDP will decrease by $\mathbf{1 . 7 2 8 0 5}$.

The coefficient of inflation shows that, with a unit increase in the explanatory variable INF, unemployment will decrease by $\mathbf{1 . 6 7 2 2 4 3}$.

\subsection{Statistical Criteria}

\subsubsection{The $\mathrm{R}^{2}$ (Coefficient of Determination)}

The $\mathrm{R}^{2}$ of the model for equation (UNEMP $=\boldsymbol{\beta}_{\mathbf{0}}+\boldsymbol{\beta}_{\mathbf{1}}$ Real GDP $+\boldsymbol{\beta}_{\mathbf{2}} \mathbf{I N F}+\mathbf{e t}$ ) is 0.60610 , showing that the explanatory variables (or independent variables) explains about $60.6 \%$ of the explained variable (dependent variable).

The $\mathrm{R}^{2}$ of the model for equation (INF $=\boldsymbol{\beta}_{\mathbf{0}}+\boldsymbol{\beta}_{\mathbf{1}} \mathbf{U N E M P}+\boldsymbol{\beta}_{\mathbf{2}} \mathbf{R G D P}+\mathbf{e t}$ ) is 0.962436 showing that the explanatory variables (or independent variables) explains about $96.2 \%$ of the explained variable (dependent variable).

The $\mathrm{R}^{2}$ of the model for equation ( RGDP $=\boldsymbol{\beta}_{\mathbf{0}}+\boldsymbol{\beta}_{\mathbf{1}} \mathbf{U N E M P}+\boldsymbol{\beta}_{\mathbf{2}} \mathbf{I N F}+$ et) is 0.951864 , showing that the explanatory variables (or independent variables) explains about $95.1 \%$ of the explained variable (dependent variable).

\subsubsection{The T-test (Student t)}

To recall, the $\mathrm{t}$-test is used to test if the independent variables are individually statistically significant to the dependent variable. Under $n-k$ degrees of freedom at $5 \%$ level of significance, the critical value is \pm 4.920 . Thus we reject $\mathrm{H}_{0}$ that the variable is statistically significant if tcal $>$ ttab in absolute values (that is, ignoring negative values) and accept, in both the equation. 
Table 11. Statistical result for model (UNEMP $=\beta_{0}+\beta_{1} \mathrm{RGDP}+\beta_{2} \mathrm{INF}+$ et $)$

\begin{tabular}{|c|c|c|c|}
\hline Variables & t-value & $\mathbf{5 \%}$ critical & Decision \\
\hline Constant & 1.696107 & \pm 4.303 & Statistically non- significance \\
\hline RGDP & 2.176178 & \pm 4.303 & Statistically non-significance \\
\hline INF & -0.56187 & \pm 4.303 & Statistically non-significance \\
\hline
\end{tabular}

Table 12. Statistical result for model (INF $\left.=\beta_{0}+\beta_{1} \mathrm{UNEMP}+\beta_{2} \mathrm{RGDP}+\mathrm{et}\right)$

\begin{tabular}{|c|c|c|c|}
\hline Variables & t-value & $\mathbf{5 \%}$ critical & Decision \\
\hline Constant & -3.02665 & \pm 4.303 & Statistically non- significance \\
\hline UNEMP & 4.269637 & \pm 4.303 & Statistically non- significance \\
\hline RGDP & 3.657237 & \pm 4.303 & Statistically non- significance \\
\hline
\end{tabular}

Table 13. Statistical result for model (RGDP $=\beta_{0}+\beta_{2} \mathrm{UNEMP}+\beta_{2} \mathrm{INF}+$ et)

\begin{tabular}{|c|c|c|c|}
\hline Variables & t-value & $\mathbf{5 \%}$ critical & Decision \\
\hline Constant & 3.138264 & \pm 4.303 & Statistically non-significance \\
\hline UNEMP & -3.46066 & \pm 4.303 & Statistically non-significance \\
\hline INF & 6.079532 & \pm 4.03 & Statistically significance \\
\hline
\end{tabular}

\subsection{Hypothesis Testing}

Null hypothesis (Ho): There is no short run tradeoff relationship between inflation and unemployment in India. Null hypothesis (Ho): There is insignificant relationship between inflation and unemployment. Null hypothesis (Ho): Real Gross domestic product (GDP) has no significant impact on unemployment in India.

From the regression result, the coefficient of inflation is negative in first model, this is showing that short run tradeoff relationship does not exists between inflation and unemployment. The co-efficient of unemployment is positive in second model. This is showing that inflation has positive effect on unemployment. It has further seen from the analysis that gross domestic product was found to be statistically non-significant in the third model. From the third model, co-efficient of inflation is positive and Statistical significance with Real GDP taken as a dependent variable. This analysis shows non- significant impact of unemployment variable on Real GDP.

$>$ It has been seen in the study that prices of commodity increases indicates higher rate of inflation in the country while reverse is true for deflation.

The available data of Inflation and unemployment it has been seen in the study that when inflation increases in the year the unemployment rate also increases in different ratio or independent ratio.

$>$ The data of inflation and employment shows inverse relation with each other, this indicates that when inflation increases the unemployment decreases. 
From the data of Real GDP and inflation having positive relation with each other, whenever the inflation take place, the GDP of the particular year will increase.

In Case of unemployment and GDP both having inverse relation with each other, this indicates that if GDP of a country will increase the unemployment will decrease, and reverse is true in case of decrease in GDP.

Therefore, we conclude that there is no trade-off relationship between unemployment and inflation in India, there is insignificant relationship between inflation-unemployment in India and Gross domestic product shows insignificant impact on unemployment in India.

\subsection{F-TEST}

This shows the overall performance of the regression model. The decision rule as stated previously is to reject $\mathrm{H}_{0}$ that the model is well specified and adequate for forecasting and policy analysis if Fcal $>$ F0.05 and accept it if otherwise.

Table 14.

\begin{tabular}{|c|c|c|}
\hline \multicolumn{3}{|c|}{ F-statistics For Model (UNEMP $=\beta_{0}+\beta_{1}$ RGDP $+\beta_{2}$ INF + et $)$} \\
\hline Fcal & Ftab at 0.05 significant level & Decision \\
\hline 4.0635 & 0.1975 & $\mathrm{H}_{0}$ reject and $\mathrm{H}_{1}$ accept \\
\hline \multicolumn{3}{|c|}{ F- statistics For model (INF $=\beta_{0}+\beta_{1}$ UNEMP $+\beta_{2}$ RGDP + et $)$} \\
\hline Fcal & Ftab at 0.05 significant level & Decision \\
\hline 38.43223 & 0.00728 & $\mathrm{H}_{0}$ reject and $\mathrm{H}_{1}$ accept \\
\hline \multicolumn{3}{|c|}{ F- statistics For model $\left(\mathrm{RGDP}=\beta_{0}+\beta_{1}\right.$ UNEMP $+\beta_{3}$ INF + et) } \\
\hline Fcal & Ftab at 0.05 significant level & Decision \\
\hline 29.6617 & 0.010561 & $\mathrm{H}_{0}$ reject and $\mathrm{H}_{1}$ accept \\
\hline
\end{tabular}

From above Table 14 the result shows that the first model is well specified and considered as being good and adequate for forecasting and policy analysis. It further states that the overall regression is insignificant and statistically different from zero.

Findings obtained are similar to Sa'idul \& Muhammad (2015), work on unemployment - inflation and economic growth, Umair \& Ullah (2013) work on real GDP, inflation and unemployment, Kotia (2013) work on Phillip's curve for India, Subhan (2010) unemployment - inflation and economic growth used same interpretation to conclude the result for other countries. Although the study of relationship between inflation - unemployment of Indian country shows same findings.

\section{Conclusion and Policy Implications}

The findings revealed that the coefficient of Unemployment is positive and statistically significant, while Inflation is negative but unemployment has no significant effect on real GDP. Thus, unemployment substantially affects Inflation, while unemployment has little substantial effect on Real GDP. 
Unemployment and inflation poses a serious problem in any economy. Studies carried out by most economists revealed that in the quest to reduce unemployment, rising inflation may be risked. A. W. Phillips research work (1958) attested to this fact of tradeoff relationship. However, some other economists led by Milton Friedman challenged the trade-off relationship thesis, saying that it exists only in the short-run, that in the long run, the Phillips curve is vertical without any sign of trade-off relationship. Friedman used the term natural rate of unemployment in his analysis denotes the rate at which the actual rate of inflation equals the expected rate of inflation. The researcher in other to validate the existence of a Phillips curve carried out various tests, using the Indian economy as a case study. The result of the test revealed that unemployment and inflation are inversely related, thus confirming the existence of the Phillips curve in India, with inflation having a significant impact on unemployment in India.

Thus, there is a need for strong institutional collaboration and link among ministries for dealing with these triplet macroeconomic variables; unemployment, inflation and real GDP in the country. Consequently, this paper suggests some policy options for the government as follows:

(1) Restructuring the economy through inward growth not along foreign borrowed ideology;

(2) Efficient modern technology to create more sustainable jobs and enhance the real wage of workers;

(3) Ensure macroeconomic management of price instability;

(4) Improving infrastructure particularly electricity which in turn may generate employment.

\section{References}

Afzal1, M., \& Awais, S. (2012). Inflation-Unemployment Trade Off: Evidence from Pakistan. Journal of Global Economy, 8(1).

Ali, A. N. M. (2011). The Dynamic Effect of Unemployment Rate on Per Capita Real GDP in Iran. International Journal of Economics and Finance, 3(5).

Al-Zeaud, H. (2014). The trade-off between unemployment and inflation evidence from causality test for Jordan. International journal of humanities and social science, special issues, 4.

Ball, L., Chari, A., \& Mishra, P. (2015). Understanding Inflation in India. India Policy forum. (NCAER) National Council of Applied Economic Research.

Das, A., \& Martin, F. (2013). The Phillips Curve The Case of Indian Data. International Journal of Advances in Management and Economics, 2(2), 163-169.

Dholakia, H. R., \& Sapre, A. A. (2011). Speed of adjustment and inflation-unemployment tradeoff in developing countries- case of India. working paper no.2011-07-01

Fei, Q., \& Qianyi, Q. (2012). The research in inflation rate and unemployment rate in China. 
International Conference on Social Science Research, (e-ISBN 978-967-11768-1-8) 4-5 June 2013 Penang, Malayasia.

Katria, S., Bhutto, N. A., Butt, F., Domki, A. A., \& Khawaj, H. A (2011). Is There Any Tradeoff between Inflation and Unemployment? The Case of SAARC Countries. Pakistan Journal of commerce and Social science, 8(3), 867-886.

Kumar, M., \& Vashist, D. C. (2012). Empirical study of Phillips curve in India. International Journal of Economic Research, 3(4), 10-25

Malam Sa'idu1, B. M., \& Muhammad, A. (2015). Unemployment and Inflation Substantially Affect Economic Growth. Journal of Economics and Development Studies, 3(2), 132-139.

Ormerod, P., Rosewell, B., \& Phelps, P. (2009). Inflation- unemployment regimes and the instability of the Phillips curve. Economics Discussion Paper No. 2009-43. http://dx.doi.org/10.2139/ssrn.1726745

Owyang, T. M., Sekhposyan, T., \& Vermann, E. K. (2013). Output and Unemployment. [Online] Available: http://research.stlouisfed.org/econ/owyang/index.html.

Ray, L. (2011). Estimation of Phillips curve in Indian context. International Journal of Economics \& Research, 3(2), 28-51.

Singh, K. B., \& Kanakaraj, A., \& Sridevi, T. O. (2010). Revisiting the empirical existence of the Phillips Curve for India. Journal of Asian Economics, 22(3), 247-258. http://dx.doi.org/10.1016/j.asieco.2011.01.002

Umair, M., \& Ullah, R. (2013). Impact of GDP and Inflation on Unemployment Rate: A Study of Pakistan Economy in 2000-2010. International Review of Management and Business Research, 2(2).

Venelina, G. T. (2013). Some Aspects of the Evolution of Inflation- Unemployment Tradeoff. International Journal of Social Science and Humanity, 3(3).

\section{Copyright Disclaimer}

Copyright for this article is retained by the author(s), with first publication rights granted to the journal.

This is an open-access article distributed under the terms and conditions of the Creative Commons Attribution license (http://creativecommons.org/licenses/by/3.0/). 